\title{
Prosthetic rehabilitation for a maxillectomy patient using 3D printing assisted closed hollow bulb obturator: a case report
}

\author{
Miju Oh, Jonghyuk Lee*, Young-Gyun Song \\ Department of Prosthodontics, College of Dentistry, Dankook University, Cheonan, Republic of Korea
}

\begin{abstract}
This case report presents a closed hollow bulb obturator made by 3D printing for a maxillectomy patient. Final impression was taken according to the instructions and impression trays provided by the Magic denture ${ }^{\mathrm{TM}}$ system. Vertical dimension, facial appearance, and retention had been checked with the try-in denture. The try-in denture was corrected and adjusted to fulfill the demand of the patients, then these were reflected to the final design of the denture. The defect area was designed as a closed hollow bulb shape to reduce the weight and to provide uniform thickness of the denture. The patient satisfied with the esthetics and function of the denture. (J Dent Rehabil Appl Sci 2019;35(3):191-8)
\end{abstract}

Key words: obturator; maxillary defect; 3D printing; closed hollow bulb

\begin{abstract}
서론
악성종양, 선천적 결손 등으로 인한 상악골 결손 환자 는 과도한 비음, 불완전한 저작 및 연하, 비강으로의 액체 누출 등의 불편을 겪게 된다. ${ }^{1}$ 이러한 불편을 해결하기 위 해 obturator라는 보철물을 사용하는데, 보철적 수복의 목표는 구강과 비강을 분리시켜서 환자에게 편안함은 물 론 저작, 연하, 심미성을 모두 충족시키는 것이다. ${ }^{2}$

그러나 완전 무치악 환자에서의 상악골 결손 환자는 obturator 수복시 불량한 예후를 보이는데, 의치의 지지, 유지, 안정에 필요한 구조물들이 부족한 경우가 많고 횡 단치열궁안정(cross arch stabilization)이 부족하기 때문 이다. ${ }^{3}$ 이를 보완하기 위해서는 의치상이 결손 부위로 충 분히 연장되어야(bulb portion) 하며, 연장된 이 부위에 서 유지와 안정을 얻어야 한다. 반면에 너무 심하게 연장 되었을 때는 보철물의 무게가 증가되어 중력에 의한 탈 락력이 발생하여 의치의 안정에 영향을 주게 된다. ${ }^{4}$ 따라

${ }^{*}$ Correspondence to: Jonghyuk Lee

Professor, Department of Prosthodontics, College of Dentistry, Dankook University, Dandae-ro 119, Dongnam-gu, Cheonan, 31116, Republic of Korea

Tel: +82-41-550-1975, Fax: +82-41-550-0255, E-mail: hyuk928@chol.com

Received: July 31, 2019/Last Revision: August 20, 2019/Accepted: August 27, 2019
\end{abstract}

서 보철물의 무게를 줄여주면서도 결손 부위로 의치가 충분히 연장될 수 있도록 hollow bulb portion을 만드는 obturator가 제시되었는데, open hollow bulb와 closed hollow bulb와 같이 두 가지 방식이 있다. Open hollow bulb는 bulb portion의 내부가 열려있고, 비어있는 형태 를 가지고 있다. 이는 만들기 쉽다는 장점이 있으나 점액, 음식물, 액체 등이 축적될 수 있어 나쁜 향과 맛을 유발 하고, 연마가 힘들다는 단점이 있다. Closed hollow bulb 는 bulb portion이 공처럼 닫혀 있지만 내부가 비어있는 공간으로 되어 있다. 수분이나 점액, 음식물들이 축적될 가능성이 적지만 의치의 매몰 및 중합 후 hollow 공간을 유지하는 물질을 빼내고, 다시 레진으로 bulb 상단부를 봉쇄하는 등 복잡한 기공실 과정이 필요하다는 단점이 있다. ${ }^{2,46}$

Computer-aided design/computer-aided manufacturing (CAD-CAM)이 소개된 이래로 상하악 총의치를 CAD-CAM으로 제작한 증례가 많이 보고되고 있다. $3 \mathrm{D}$ 
printing은 3차원으로 된 정보를 입력 받아 재료의 층들 을 연속적으로 쌓아 물체를 원하는 형태로 만드는 것으 로서 $\mathrm{CAD}-\mathrm{CAM}$ 제작방식 중 하나이다. 이 과정은 첨 가술(additive manufacturing)이라고 불리며, 또한 rapid prototyping이라고도 알려져 있다. 3D printing에 있어서 computer-aided design (CAD) 소프트웨어는 필수적인데, $\mathrm{CAD}$ 는 해부학적 구조물을 디지털 데이터로 바꾸고 특정 소프트웨어 프로그램을 이용해 데이터를 수정하며 제작 하는 기계에 정보를 준다. ${ }^{78} \mathrm{CAD}-\mathrm{CAM}$ 을 이용한 의치는 환자의 내원 횟수를 줄이고, 디지털 데이터로 저장이 되 어 언제든지 파일을 불러 올 수 있다는 장점이 있다. 또한 중합 수축이 없어 오차를 줄일 수 있으며, 제작 공정 과정 에서 수작업에 의한 실수를 줄일 수 있다. ${ }^{9}$

최근 $\mathrm{CAD}-\mathrm{CAM}$ 을 이용해 총의치를 제작한 의치 증례 는 보고되었으나 3D printer를 이용하여 closed hollow bulb 형태의 obturator를 제작한 증례는 없었다. 본 증례 는 악성종양으로 상악골을 절제하여 상악골이 부분적으 로 결손된 완전 무치악 환자에서 $3 \mathrm{D}$ printing을 이용하 여 closed hollow bulb형태의 obturator를 제작한 증례를 보고하고자 한다.

\section{증례보고}

환자는 66세 남성으로 2018년도 2월부터 4월까지 재 발성 상악동 종양(recurrent sinus cancer)으로 항암화학 요법과 방사선요법을 받았고, "암 수술 한 위턱에 틀니를 하고 싶다"는 주소로 내원하였다.

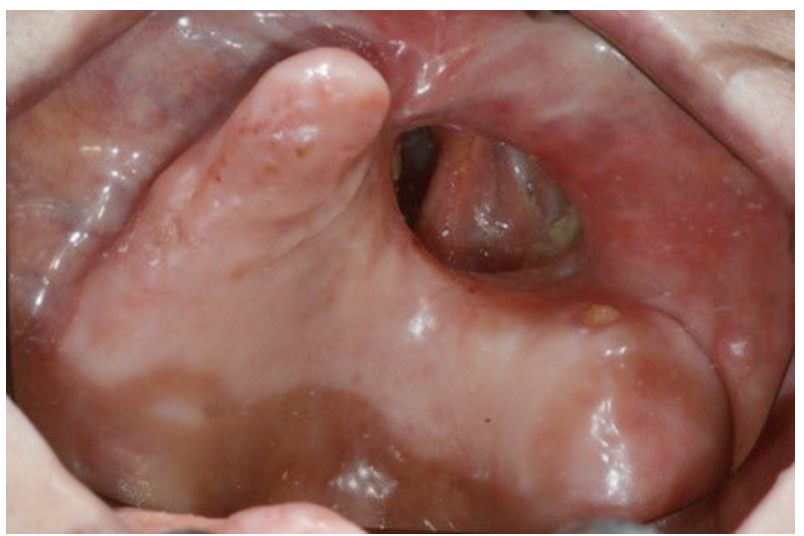

Fig. 1. Intraoral view. Fully edentulous ridge with partial resection of the left premaxillary area.
구강 검사시 상악은 완전 무치악 상태였고, 좌측 전상 악골 부위에 $3 \times 2.5 \mathrm{~cm}$ 크기의 결손부가 관찰되었다. 상 악골 결손부위를 제외한 나머지 치조정 부위에는 언더컷 이 존재하고, 구개부위가 건전하였다. 총의치 형태의 보 철물 제작시 잔존치조제, 결손부위의 언더컷 및 건전한 구개부로 인해 유지, 지지, 안정이 충분히 얻어질 것으로 판단되었다(Fig. 1). 하악은 \#31,32,33,37,41,42,46,47 치 아 결손이 관찰되었다. 구외 검사시 수술 후 반흔으로 인 해 좌측 입술과 비익 부위에 반흔 수축이 관찰되어 비심 미적이었다(Fig. 2A, 2B). 방사선 사진 검사 시 좌측 상악 골 전방부위에 상악동까지 이어진 결손부위가 관찰되었 고, \#33,42번 부위 임플란트 고정체 식립이 확인되었다 (Fig. 3). Brown의 분류법 ${ }^{10}$ 에 따르면 수직적으로 안와골 하벽을 포함하지 않는 상악골 결손 부위 및 수평적으로 상악골 절반과 동일하거나 그 이하의 편측 상악골 결손 부위로 Class $2 \mathrm{~b}$ 에 해당하였다.

위와 같은 검사 결과를 바탕으로 상악은 총의치 형태 의 closed hollow bulb obturator 보철물을 제작하기로 하였다. 전통적인 방식으로 closed hollow bulb 형태의 obturator를 만들게 되면 기공과정이 복잡하고, 오차가 발생할 가능성이 커 $3 \mathrm{D}$ printing을 이용하여 obturator를 제작하기로 계획하였다.

환자의 수직 고경의 적절성 여부 및 안모 평가를 위해 가철성 임시 의치를 제작하여 3 개월 간 사용하였다. 가철 성 임시의치 사용시 좌측 안모의 반흔 수축으로 인해 입 이 다물어지지 않음을 확인하고 최종 의치에서는 좌측 의 입술지지(lip support)를 최대한으로 줄여 반영하였다
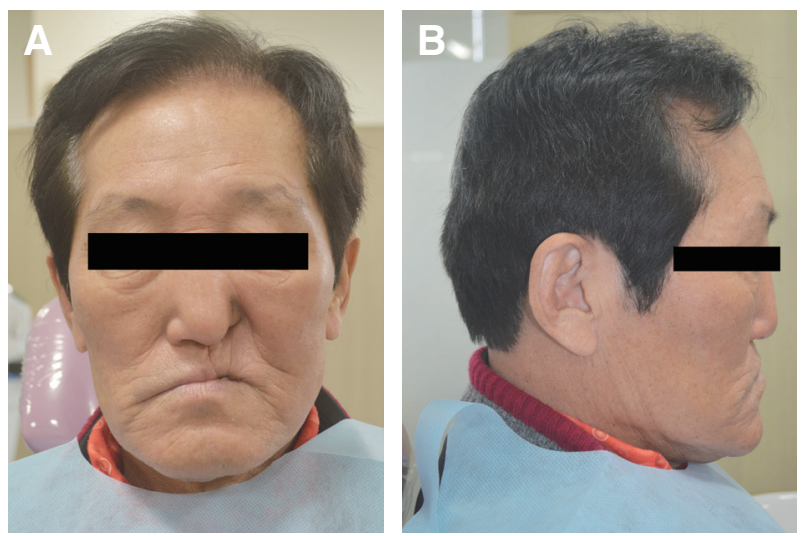

Fig. 2. Extraoral view (A) and lateral view (B). Facial depression and scar contracture on the left nasal alar area and the left mouth angle were seen. 


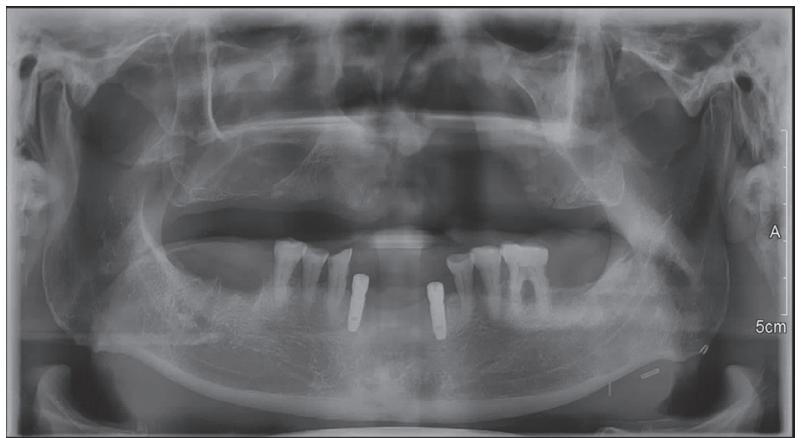

Fig. 3. Panoramic radiograph. Maxillary defect on the left sinus area was observed.

(Fig. 4). 이를 통해 근육 긴장도를 줄여 심미적인 안모 외 형을 기대할 수 있으나, 인공치아 부분까지 입술지지를 줄이게 되면 수평피개가 감소되어 오히려 비심미적으로 보일 수 있으므로 치아 부분은 제외하고 전정 부위만 입 술지지를 줄이기로 계획하였다.

최종 obturator는 Magic denture ${ }^{\mathrm{TM}}$ (Cozahn, Seoul, Korea) 시스템을 이용하여 제작하였다. 환자의 구강에 맞는 Magic denture의 트레이를 선택한 후 과연장된 변 연과 내면을 버로 다듬어 조절하였다. 상악 좌측 결손부 위에 거즈를 삽입한 후 폴리비닐실리콘인상재(Delikit heavy body, happiden, Busan, Korea)를 담은 트레이를 이용해 1차 인상을 채득하였다(Fig. $5 \mathrm{~A}$ ). 이 때 뺨과 입술 을 손으로 잡아 기능운동을 시켜 변연형성을 시행하고 4분 후 구강에서 제거하였다. 그 후 다시 폴리비닐실리 콘인상재(Honigum light body, DMG, Hamburg, Germany)를 담고, 구강내에서 2차 정밀 인상을 채득하고 구 강에서 제거하였다(Fig. 5B). 인상을 채득한 상악 트레 이 중간 부위를 \#15 blade로 조심스럽게 잘라 분리한 후 트레이 전방부만 상악에 다시 시적하고, 하악에는 lower attachment plate를 시적하여 Magic denture ${ }^{\mathrm{TM}}$ 에서 제공 하는 묘기침(Gothic arch tracer)으로 높이를 설정하였다 (Fig. 5C). 수직고경 설정 시 Jaw gauge로 기존 임시의치 의 높이와 동일하게 설정하였다. 또한 중심위 채득을 위 해 Magic denture에서 제공하는 EZ-tracer를 상악 트레 이 하방에 부착한 후 하악을 전후방, 측방으로 운동시켜 고딕아치트레이싱(Gothic arch tracing)을 시행하였다 (Fig. 5D). 그 후 상악 트레이와 하악의 attachment plate 사이에 교합인기재(I-Sil bite, Spident, Incheon, Koera) 를 이용해 공간을 채워 악간관계를 인기하였다. 인상을 채득한 상악 트레이, 교합인기재, 하악 attachment plate 를 고정하여 분리하지 않은 상태로 Magic denture ${ }^{\mathrm{TM}}$ 기 공소에 의뢰하였다.

약 1 주일 후 상악 obturator의 치아배열 및 결손부 모 양 데이터를 확인하였고, 그로부터 다시 1 주일 후 시적의 치를 제작하여 시적하였다. 시적의치상에서 지지가 부족 하여 의치의 움직임이 있었고, 수직고경이 기존 임시의치 보다 $3 \mathrm{~mm}$ 가 높았다. 또한 좌측 반흔 수축으로 인해 의 치가 노출되는 부분이 많았다. 따라서 시적의치의 수직 고경을 감소시키고, 좌측 순측 부위의 입술지지를 줄인 후 wash 인상을 채득하여 다시 기공소로 보냈다(Fig. 6). 수직고경을 확인하기 위하여 두 번째 시적의치를 제작하 였고, 입술지지나 외형 및 적합도 평가를 해보았을 때 적 절하였다.

Closed hollow bulb 형태를 만드는 과정은 magic denture로부터 두 번째 시적의치의 STL file을 받아 CAD 프 로그램(Meshmixer, Autodesk, San Rafael, USA)을 이용 해 직접 내부가 비어있는 형태로 디자인 하였다(Fig. 7). 결손부위의 의치 두께는 $2 \mathrm{~mm}$ 로 하였고, 의치상 및 치아 를 프린팅하여 레진으로 접착하였다. 반흔수축으로 인 해 상악 전치부 입술면쪽이 노출되는 것을 고려하여 자
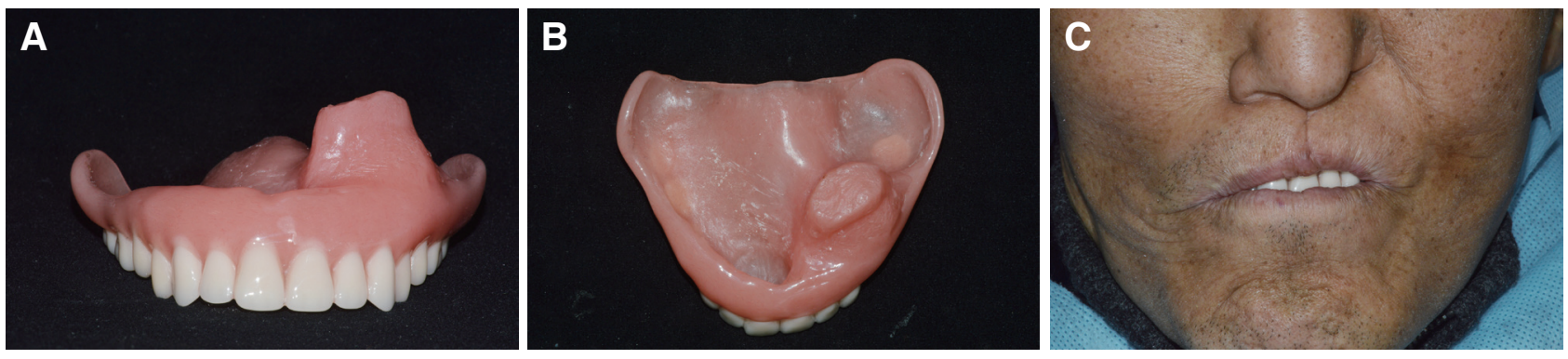

Fig. 4. Temporary obturator (A, B). Artificial teeth were exposed due to the scar contracture and the temporary obturator's excessive lip support (C). 
A
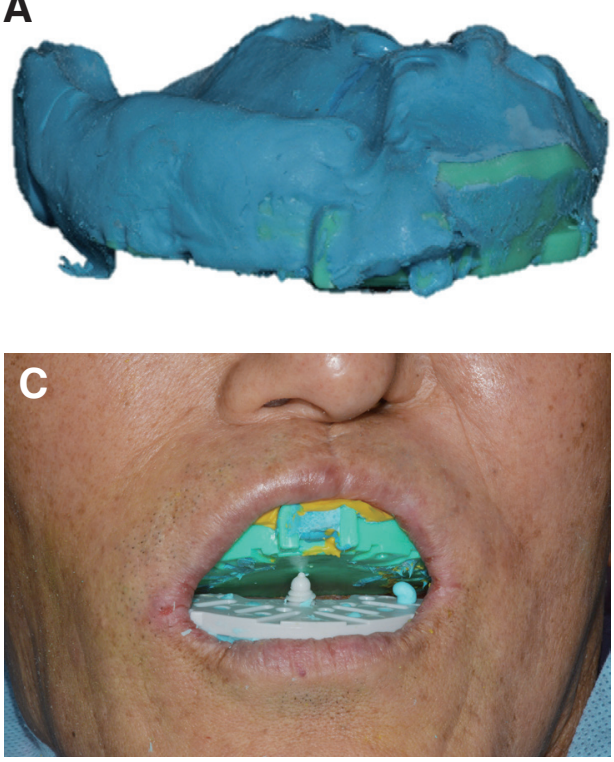

B
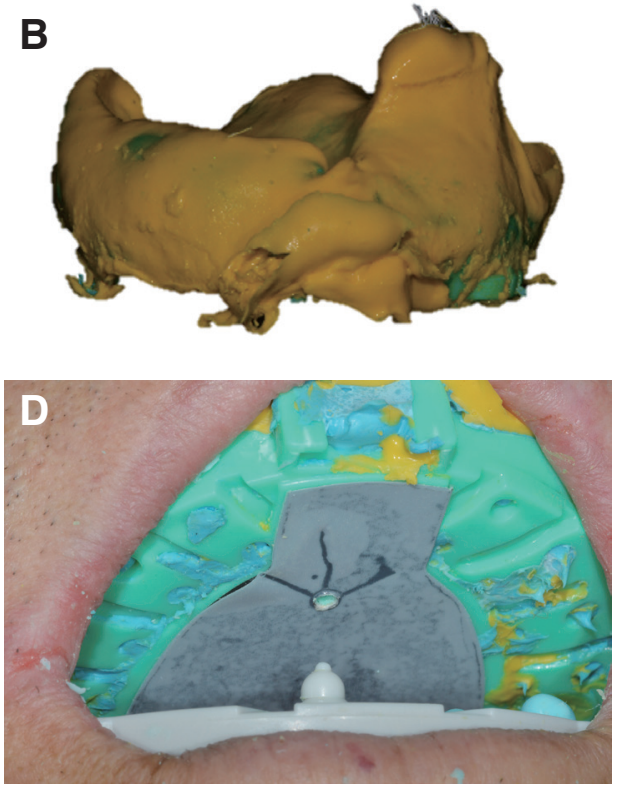

Fig. 5. Final impression of CAD-CAM obturator by the Magic denture system. 1st impression with heavy body PVS material (A). 2nd wash impression with light body PVS material (B). Vertical dimension determination and centric relation record with the Gothic arch tracing device $(C, D)$.
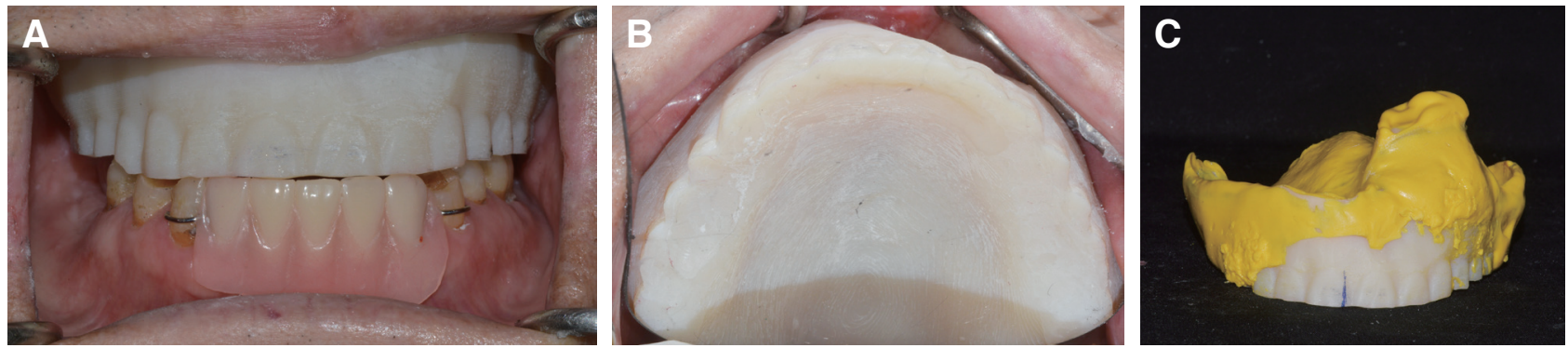

Fig. 6. After the correction of the try-in denture's vertical dimension (A), Lip support (B). Wash impression made with the try-in denture $(\mathrm{C})$.
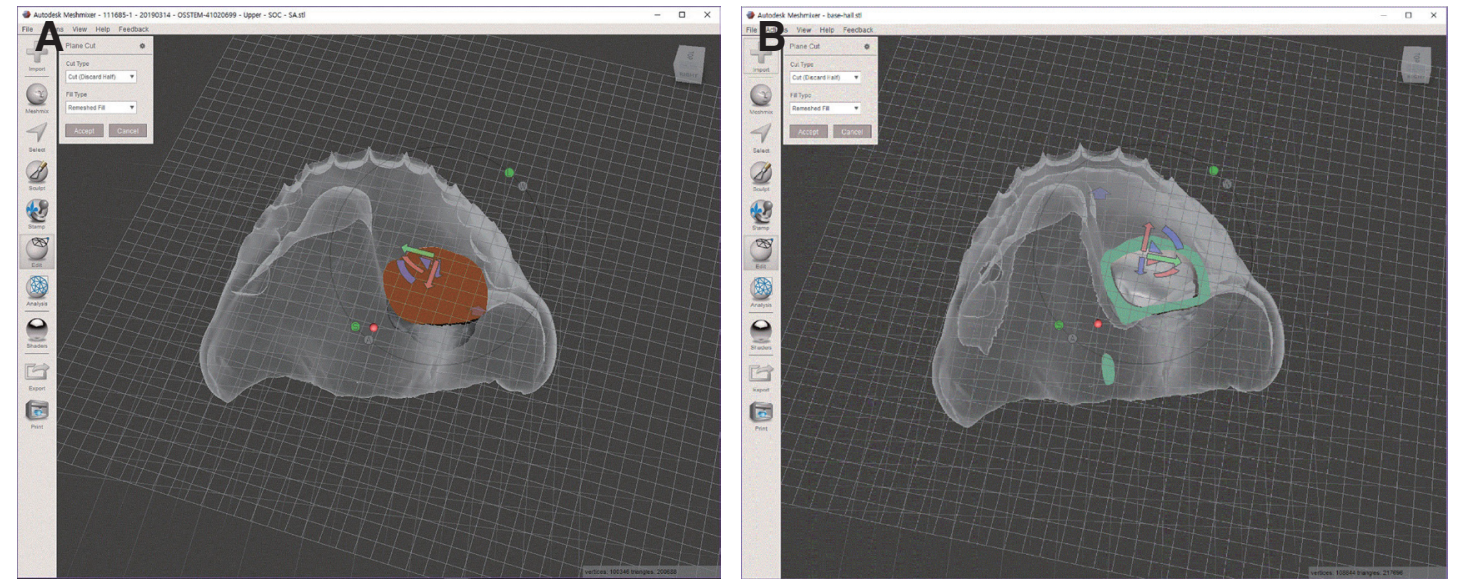

Fig. 7. STL file the bulb portion was not hollow (A). The bulb portion was redesigned in the shape of hollow bulb (B). 

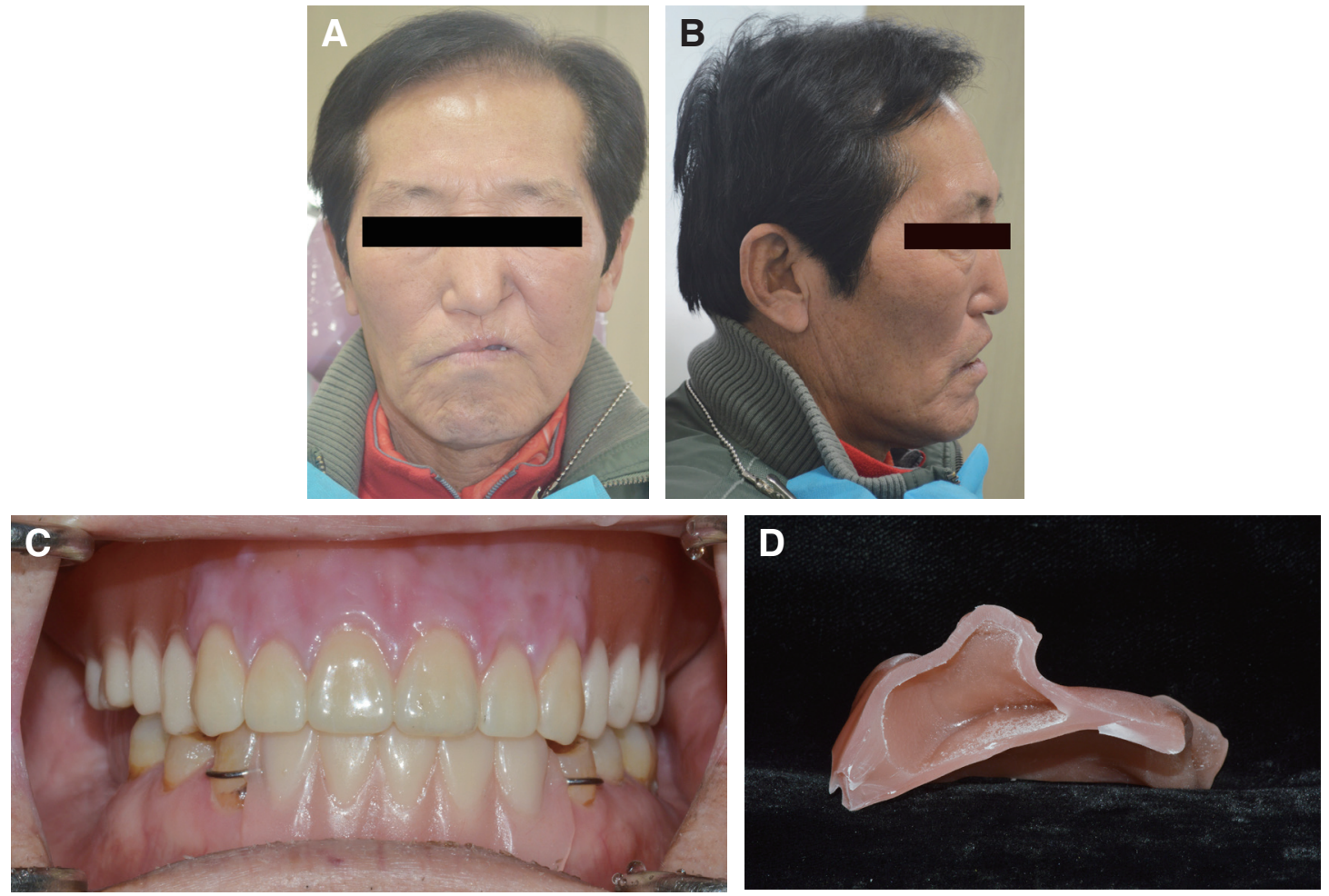

Fig. 8. Final obturator. Extraoral view with the obturator in place (A, B). Intra oral view (C). Hollow space inside the bulb portion of the CAD-CAM obturator (cross sectioned) (D).

연스러운 잇몸색깔 구현을 위해 레진(Nextcore, Ivoclar vivadent, schaan, Liechtenstein)을 이용하여 치은 및 인 공치아의 착색을 시행하였다.

최종 obturator 시적시 심미 및 입술이 다물어질 수 있 다는 것에 대해서 환자는 만족해 하였고, 의치의 유지 및 지지 또한 우수함을 볼 수 있었다(Fig. 8). 환자에게 의치 사용시 주의사항을 설명하였고, 주기적인 정기검진 또한 필요함을 설명하였다. 의치 사용 24시간 후 재내원하여 과도한 압박 및 통증부위를 조절하였다. 정기검진에서 조직상태 양호함을 관찰하였고, 의치에 수분이나 점액이 축적됨이 없이 위생관리가 잘 되고 있음을 관찰할 수 있 었다.

\section{고찰}

상악골 결손 환자에서 의치 제작시 의치상을 결손부위 로 연장하여 유지와 안정을 얻는다. 그러나 결손부위로 연장시 크기와 무게가 증가하여 오히려 유지력이 떨어질 수 있어 무게를 최소화 하기 위해 open hollow bulb 또는 closed hollow bulb obturator가 사용된다. 이 중에서도
점액질, 수분, 음식물등의 축적을 줄이고 위생관리를 위 해서는 closed hollow bulb obturator가 추천된다. closed hollow bulb obturator 제작을 할 때 설탕, 소금, 얼음 등 과 같은 물질들을 bulb 내부에 넣어 기공 과정중에 bulb 가 빈 공간으로 있을 수 있게 지지하는 수많은 방법들이 제시되어 왔다., ${ }^{411-13}$ 이러한 방법들은 기공 과정이 복잡하 고 hollow bulb 주위의 의치상 두께가 일정치 않으며, 아 크릴릭 레진을 오염시킬 수 있고, 누출이나 변색을 일으 킬 수도 있다. ${ }^{14}$ 본 증례에서는 $3 \mathrm{D}$ printing을 이용하여 closed hollow bulb otburator를 제작하였는데, 이 과정 을 통해 bulb 내부가 비어있는 상태로 쉽게 디자인할 수 있어 복잡한 기공 과정과 오차를 줄일 수 있었으며, 의치 벽의 두께를 일정하게 유지할 수 있었다. 또한 디지털 데 이터를 저장할 수 있어 추후 의치를 교체하거나 여분의 의치를 만들 때 빠르게 재제작할 수 있다는 장점이 있다.

본 증례에서 1 차 시적의치를 시적시 좌측 순측 부위의 의치상 레진이 많이 보여 비심미적이었으며, 기존 임시 obturator보다 $3 \mathrm{~mm}$ 수직고경이 높아진 것을 볼 수 있었 다. 좌측 순측 부위의 의치상 레진이 많이 노출되었던 것 은 과도한 입술 지지 및 높은 수직고경 때문일 것으로 생 
각되었다. 과도한 입술 지지 및 높은 수직고경은 입틈새 (oral fissure)를 위쪽으로 변화시키며, 상순과 하순의 홍 순(vermillion) 높이를 증가시킨다. ${ }^{15}$ 입술 지지는 입술 뒤 쪽에 위치한 조직들이 입술을 밀어내어 입술 외형뿐만 아니라 입술, 턱 주름에 영향을 끼칠 수 있어 자연스러운 안모 형성에 크게 기여하는 인자이다. ${ }^{16}$ 입술 지지의 변화 는 입술, 입틈새와 같은 구조물들의 위치를 바꿀 수 있으 며, 상순과 하순의 접촉 강도의 변화를 일으킨다. 따라서 이 증례에서는 우측보다 좌측의 입술 지지를 많이 줄여 서 반흔 수축부위에 긴장이 가해지지 않도록 하였으나, 반흔 수축이 있는 경우 입술 지지를 줄여 심미적 안모를 개선하는 것은 한계가 있으므로 추후 수술적 치료가 필 요할 것으로 생각된다.

수직 고경이 높아지는 것으로 추정되는 원인으로는 양 악이 모두 무치악인 경우보다 편악일 때의 CAD-CAM용 상악 기성 트레이, 하악 attachment plate의 사용이 더 어 렵기 때문인 것으로 추정된다. 그러나 현재 CAD-CAM 으로 편악 총의치 제작시 고려해야 할 사항에 대해서는 연구된 바가 없어 추가적인 연구가 필요할 것으로 사료 되며, 수직고경에 대한 오차를 줄이기 위해서는 환자에 게 적합한 트레이를 사용하고 최종 인상시에 정밀한 인 상을 채득하여 인상재의 두께가 두꺼워 지지 않도록 하 는 것이 필수적일 것으로 생각된다.

또한 인상채득과 수직고경 결정 과정 중에 오차가 생 긴 경우 시적의치상에서 새로 인상을 채득하거나 교합면 을 삭제하여 새로 교합관계를 기록하면 이를 다시 스캔 하여 최종의치에 반영할 수 있어 편악 CAD-CAM 의치 제작시에는 시적의치 과정을 추가하여 오차를 반영하여 수정하는 것이 필요할 것으로 생각된다.

\section{결론}

본 증례는 Brown 분류법 class $2 \mathrm{~b}$ 에 해당하는 상악골 결손 환자에서 $3 \mathrm{D}$ printing을 이용한 obturator로 편악 수복한 증례이다. 보철 수복과정에서 시적의치의 약간의 조정 및 수정 과정이 필요하였다. 이를 통해 내원횟수가 늘어나 기존의 CAD-CAM 의치의 장점인 내원횟수 감소 측면에서는 뚜렷한 장점이 나타나지 않았다. 상악골 결 손 부위는 closed hollow bulb 형태로 만들어 무게를 줄 이고, 점액이나 수분 침착을 줄여 위생적인 상태와 충분 한 유지력을 얻을 수 있었다. 환자는 심미성과 유지력 측 면에서 $3 \mathrm{D}$ printing obturator에 만족감을 느꼈고, 이후
정기적인 검진에도 양호한 결과를 보였다. 결손된 부위와 잔존 치조골의 상태를 고려하여 상악골이 결손된 완전무 치악 환자에서의 closed hollow bulb형태의 3D printing obturator의 제작은 손쉬운 제작 및 심미성 측면에서 만 족스러운 방법인 것으로 생각된다.

\section{Acknowledgements}

3D printing 의치는 2019년 (주)코잔의 지원을 받아 제 작되었음.

\section{ORCID}

Miju Oh https://orcid.org/0000-0001-8863-7679

Jonghyuk Lee https://orcid.org/0000-0003-1976-4089

Young Gyun Song https://orcid.org/0000-0003-3789-9585

\section{References}

1. Irish J, Sandhu N, Simpson C, Wood R, Gilbert R, Gullane P, Brown D, Goldstein D, Devins G, Barker E. Quality of life in patients with maxillectomy prostheses. Head Neck 2009;31:813-21.

2. Keyf F. Obturator prosthesis for hemimaxillectomy patients. J Oral Rehabil 2001;28:821-9.

3. Wang RR. Sectional prosthesis for total maxillectomy patients: a clinical report. J Prosthet Dent 1997;78:241-4.

4. Buzayan MM. The hollow bulb obturator fabrication, where do we stand in 2017. Periodont Prosthodont 2017;3:10.

5. Brown KE. Fabrication of a hollow-bulb obturator. J Prosthet Dent 1969;21:97-103.

6. Krishna CH, Babu JK, Fathima T, Reddy GV. Fabrication of a hollow bulb prosthesis for the rehabilitation of an acquired total maxillectomy defect. BMJ Case Rep 2014 Mar 26;2014. pii: bcr2013201400. doi: 10.1136/bcr-2013-201400.

7. Dawood A, Marti Marti B, Sauret-Jackson V, Darwood A. 3D printing in dentistry. Br Dent J 2015;219:521-9.

8. Tasopoulos T, Kouveliotis G, Polyzois G, Karathanasi V. Fabrication of a 3D printing definitive obturator prosthesis: a clinical report. Acta Stomatol 
Croat 2017;51:53-8.

9. Kattadiyil MT, Jekki R, Goodacre CJ, Baba NZ. Comparison of treatment outcomes in digital and conventional complete removable dental prosthesis fabrications in a predoctoral setting. J Prosthet Dent 2015;114:818-25.

10. Brown JS, Rogers SN, McNally DN, Boyle M. A modified classification for the maxillectomy defect. Head Neck 2000;22:17-26.

11. Habib BH, Driscoll CF. Fabrication of a closed hollow obturator. J Prosthet Dent 2004;91:383-5.

12. Sreeramulu B, Shalini K, Swapna B, Suman P, Venkata Ratana Kumar R. Alternative technique for fabrication of hollow bulb obturator for hemimaxillectomy patient - a case report. Int J Healthcare Biomed Res 2014;3:139-43.

13. Patil PG, Nimbalkar-Patil S. Lost wax-bolus tech- nique to process closed hollow obturator with uniform wall thickness using single flasking procedure. J Indian Prosthodont Soc 2017;17:84-8.

14. Shrestha B, Hughes ER, Kumar Singh R, Suwal P, Parajuli PK, Shrestha P, Sharma A, Adhikari G. Fabrication of closed hollow bulb obturator using thermoplastic resin material. Case Rep Dent 2015;2015:504561.

15. Ushijima M, Kamashita Y, Nishi Y, Nagaoka E. Changes in lip forms on three-dimensional images with alteration of lip support and/or occlusal vertical dimension in complete denture wearers. J Prosthodont Res 2013;57:113-21.

16. Kamashita Y, Kamada Y, Kawahata N, Nagaoka E. Influence of lip support on the soft-tissue profile of complete denture wearers. J Oral Rehabil 2006;33:102-9. 


\section{상악골 결손부 환자에서 3D printing을 이용한 closed hollow bulb obturator 수복 증례}

\section{오미주, 이종혁*, 송영균}

단국대학교 치과대학 치과보철학교실

본 증례는 상악골 결손이 있는 무치악 환자에서 3D printing을 이용해 closed hollow bulb obturator로 수복한 증례이다. Magic denture ${ }^{\mathrm{TM}}$ 시스템(Cozahn, Seoul, Korea)에서 제공하는 트레이와 인상법을 이용하여 구내 인상을 채득하였고, 시 적의치상에서 수직고경과 안모, 유지력 등을 확인하였다. 환자가 요구하는 바와 오차를 시적의치에서 수정한 후 이를 반 영하였다. 의치의 무게를 줄이고 균일한 두께를 부여하기 위해 상악골 결손부위를 closed hollow bulb로 디자인하여 최 종의치상을 프린팅하였다. 치료 후 심미적 및 기능적으로 만족스러운 결과를 얻었기에 이를 보고하는 바이다.

(구강회복응용과학지 2019;35(3):191-8)

주요어: obturator; 상악골 결손; 3D printing; closed hollow bulb 